Society and Economy 31 (2009) 2, pp. 193-209

DOI: $10.1556 /$ SocEc.31.2009.2.3

\title{
EUROPEAN STUDIES: TAKING STOCK AND LOOKING AHEAD
}

\author{
LÁSZLÓ CSABA \\ Full Professor, Central European University, Member of the Hungarian Academy of Sciences. \\ Email: csabal@ceu.hu
}

\begin{abstract}
This essay is an attempt to generalize experiences of Central and Eastern European universities in the field of European Studies over the past 20 years. The paper follows the logic of business analysis in order to come up with proposals for future action.
\end{abstract}

Keywords: ???

JEL codes: ???

\section{TRANSITION IN AND TOWARDS EUROPE}

Commemorating the $20^{\text {th }}$ birthday of the annus mirabilis in Europe allows for and even triggers broadish overviews of what has been achieved. This is already a period worth analyzing even in terms of history, long enough for drawing some preliminary conclusions. In the following pages we try to assess, with the benefit of hindsight, the intellectual plane of what is increasingly called as Europeanization in the international literature. Transition from totalitarian to democratic regimes has fundamentally reshaped the role and modus operandi of education in general and higher education in particular. Democratization implied explosive increases in student numbers, replicating the Western European experiences of the post-1968 period in much poorer societies. Moreover, the interplay between EU level and domestic forces of policy-making has created entirely new challenges on a number of planes. These included re-shaping the curricula in line with the reorientation of trade and political relations from East to West, the speedy and often 
forced convergence of curricula, in line with the so-called Bologna process of creating the uniform European space of higher education. But also hand in hand with the former, student and faculty mobility, way above anything conceivable in the preceding decades, in terms of numbers, depth and intensity, has become the name of the game.

These processes have by no means been confined to the post-membership period. The defining processes have already emerged in the 15-year - in the case of Bulgaria and Romania 18-year - long accession period. The Bologna process, but generally speaking, the European aspiration, in terms of political strategy, properly identified with convergence to EU standards, for good or bad, has shaped the organization as well as substantive features of higher education all across Europe. This holds a fortiori to countries where the elite has opted for the European perspective, even if the latter is far from being an immediate one, as in the case of the Balkan countries (Trauner 2009). The field of European Studies, covering a variety of disciplines and multidisciplinary courses offered on the EU, both at the regular and postgraduate levels, has required the production of a large amount of teaching materials, academic analyses and policy supporting background studies alike. Research financed by programs like the PHARE, followed by the pre-accession funds and more recently by the Framework Programs, as well as via a number of bilateral and multilateral initiatives, not necessarily passing through the channels of Brussels have all contributed to the deepening and widening of the area.

It would be hard to delineate the features that are specific to our area of investigation, and would not be predominated by those fundamental features described above. First and foremost, the expansion of student numbers and the expansion of courses have led to the rule of quantitative considerations over the qualitative aspects, which we shall analyze below. The need to launch the necessary amount of courses often irrespective of the qualification of the faculty, exacerbated by the quantity - i.e. input-related financing of establishments of higher education - has led to conspicuous results, and forseeable weaknesses. This will be covered in most of our study, in which we offer a management-inspired view of the subject, which may help overcome inefficiencies.

If we accept the controversial insight that higher education and research is a part of the overall competitiveness of any economy (more on that in Török 2008), it might make perfect sense to conduct such a broad but targeted screening. It goes without saying that our attempt is anything but exhaustive. Furthermore, acknowledging the limitations that follow from our narrow angle, we do not even attempt to provide an all-inclusive multidimensional assessment of progress made in the broad field of higher education. The latter followed, to a large degree, improvisations and experimental spirit of the changing governments, as well as the standing pressure that has come from society. The latter implies pressure from re- 
gional municipalities and chambers of trade and industry to establish and protect the schools of their own, even at the cost of lesser quality. Schools are often elevated to university level to ensure the prestige of the region. Secondly, pressures from a democratizing society have led to increases in enrollment rates from 4-5 per cent of the cohorts in the late 80 s to 45 per cent and more by the time of writing. Those pressures have often taken little note of feedback from labor markets. Thus the overproduction of humanities, law and business degrees at the detriment of science and engineering has become a commonly known misdevelopment, impacting negatively the international competitiveness of the country in the long run (Kádár 2008).

In the following, we take these global trends, as well as the idea of replacing the traditional Humboldtian research university with a college of mass education, managed as a corporate unit (Polónyi - Szilágyi 2008) and analyze what it has brought to European Studies and how it influences cooperation in research. We shall take Hungary as a case study of analysis owing to our familiarity with the subject, as well as due to limitations of time and space. Whenever appropriate, comparative comments will be extended, based on field experience, to other new member-states of the European Union, but without attempting to provide a detailed academic documentation and substantiation of each and every claim. We first will see strengths, then weaknesses, after which organization and tasks, following the established logic of business analyses. Finally we uncover potentials for the future, which is the purpose of the entire exercise.

\section{WHAT HAS BEEN ACHIEVED?}

It would be improper to interpret the developments in any field torn out of context. The major mission of the first two decades was to provide the physical and intellectual infrastructure to satisfy the quantum jump in demand for people versed in European affairs. While in the first period these people were rallying around the Ministry of Foreign Affairs, and especially the Office of the Prime Minister, entrusted with managing association and later accession talks, this has never been the entire story. By virtue of opening up of markets and societies, with the introduction of free trade and current account convertibility, spontaneous movement of people on the grand scale has become a formative process. In other words, not only high politics, but low politics was at hand. Besides top positions in the academia and in the state administration, foreign direct investment (FDI) has also created a large demand for people skilled in this area, especially in Hungary, which was the frontrunner in terms of FDI. Moreover, with the various waves of privatization, ending up in sizable foreign penetration of local assets in all the countries 
concerned (Winiecki, ed. 2009) and in Hungary in particular, this market demand has turned into a lasting and sustained phenomena. Surrounding the flagships of the economy - banks and large export industries - local municipalities, small businesses and state organs like the police and medical care have also created massive demand for people with qualifications over and above the minimal language skills.

In this context it is a remarkable achievement that in the case of Hungary, but also in most other new EU states, the previous exclusive focus of university level training on the capital city has been weakening. Territorial and institutional decentralization has been the name of the game, lending support to the slogan of Europe of Regions. In Hungary the tradition of training people in European affairs used to be concentrated to Budapest. By the time of writing this paper the universities of Debrecen, Szeged, Győr, Pécs and Gödöllő have joined Budapest, which launched several new programs (Farkas, ed. 2007).

This favorable process was further strengthened by the establishment of new Ph.D. schools in many universities. These allowed for the production of a new generation of researchers and faculty, trained in standard EU curricula, rather than the previously dominant ideologically and legally overloaded teaching materials. Young scholars could capitalize on the growing and extensive mobility programs, starting up with PHARE and TACIS, later with Erasmus and various bilateral arrangements.

As a result the discourse as well as the curricula have undergone a fair degree of professionalization and standardization, reflecting the requirements of markets and state administration alike. Regular attendance of conferences abroad have also helped considerably. Curricula, both at the BA and graduate levels, reflect the debates and accomplishments (along with the shortcomings) of the rather pragmatic debates in the old member-states on the nature and future of the EU. For this reason, as the other side of the same coin, relatively few new ideas have been presented by Hungarians (and other citizens of the new member-states) on the future of the EU. This has been the case notwithstanding the remarkable innovation introduced already during the Laeken Constitutional Convention in 2002-2003, when candidate countries were invited to participate in the discourse over the future of the EU. The latter have behaved, regretfully, a bit overdisciplined, not wishing to get into conflict with any of the incumbents. As a result the culture of controversy, implying the civilized, peaceful and often visionary exchange of opinion over truly strategic issues, such as the European Neighborhood Policy, the reform of the Common Agricultural Policy, the revision of cohesion policies and the reinterpretation of the Lisbon Agenda all tended to take place without active involvement and measurable intellectual input from and by the new members-states (more on that in Csaba 2008). On the other hand, this type of 'useful 
knowledge' did allow for masses of graduates to cope with the practicalities of everyday life in the EU, from the academia to business areas.

European Studies in the new members, and also in Hungary, tended to be constructed in a multidisciplinary fashion. While the dominance of legal and political approaches have been pre-eminent, for understandable reasons such as traditions and the practical needs of the association and accession negotiations, economic approaches were also present from the very outset, including monographic treatises (the monograph of Palánkai 2004 being an eminent example). These economic approaches tended to follow the mainstream of the literature on European integration and conveyed a number of established theoretical and policy insights to the university audience. It is worth mentioning that most other monographs devoted to the subjects were also either entirely descriptive - of policies and institutions as they stand today - or of immediate policy relevance, such as analyzing various aspects of the bargaining, or the implications of policy modifications on the new members.

It is relatively rare to find policy analyses that adopt a broader angle and discuss matters of relevance for the broader European Community. An example of the latter is the monograph of Inotai (2007) discussing the challenge posed by the western Balkans to the Common Foreign and Security Policy. The common thread of the books - and the large number of articles not specifically cited from journals devoted mainly or exclusively to the subject matter - is their rather pragmatic and multidisciplinary approach, where narrowly economic/econometric modeling, political science theories or IR theories, or purely sociological approaches would count among the rarities. Meanwhile, attempts to combine insights of two or more of these is the main theme in most of the contributions on the subject.

Last but not at all least we may mention that European Studies tended to be narrowly area specific in their nature, which means two types of features. First, we rarely find analyses devoted to broader issues of EU external relations, be that the role of the EU in the WTO, transatlantic debates, EU relations with the Mediterranean or potentials for cooperation with Asia and Latin America. In a way Eastward enlargement and its consequences have become dominant to a perhaps unhealthy degree. Second, we find a lot of quantitative, descriptive and normative pieces on how EU membership will, should and has exerted influence on the new members, but comparative perspectives are hard to find. Comparisons, if any, are usually made to periods of affluence, rather than analyzing the impacts of identical Community policies on different country groups in the same period.

While this parochialism is to some degree understandable, as one following from the demand of public opinion molded by the mass media, it often has contributed to a false understanding of the process of Europeanization. In part fol- 
lowing the political demand for mobilization in favor of the EU, but also in part following intellectual convenience, enlargement tended to be measured against the practices of Southern enlargement. This is a fallacy, since (1) the EC has deepened into EU since then and (2) the propensity to fund new projects by the net contributor countries has been steadily on the decrease. Not least triggered by the fierce debates on the efficiency of Community spending, that followed the downfall of the Santer Commission in 1999, amidst allegations of gross irregularities in spending practices net contributors led by Britain, the Netherlands and also the Scandinavian countries, have followed with watchful eyes any new spending items that might have appeared. Public opinion in general - and in France and Germany most specifically - has been developing a positive distaste for any common spending, and for spending in the new members, that could have been followed from the old solidarity principle of the Union in particular. Allegations about the disproportionate occurrence of corruption, petty and large scale, in Community spending in the East still count among the journalistic platitudes (althouh major misdeeds so far have only occurred in the old members).

Under these circumstances, public opinion in the East tended to feel cheated, as the major injection of money, a replication of the experience of cohesion countries never materialized. While I tend to see this as a plus, the ritual reference of public figures and analysts to the proverbial 4 per cent of GDP, received in certain exceptional years by Ireland and Greece, has figured high on the agenda of Eastern discourses. The compromise of 2002, hammered out in the Copenhagen Council that allowed for funding Eastward enlargement for ten countries (while the financial guideline accounted for a maximum of six, mostly small nations), has led to inequality in spending, both in CAP and in cohesion funds. This feature has been ruthlessly exploited by the political class. The EU, not spending as much as it should, while requiring all sorts of nonsensical standards to be met - normally referring to the environmental and food safety acquis - has become a frequent scarecrow in domestic policy debates. The benefit of the same development is perhaps the enhanced attention of the public opinion on European matters and the relevance of the EU, both as an academic and a policy subject. The weak point is the disenchantment, which has come often too early and without sound empirical justification. Academic output, in its most part, tended to follow rather than shape the tendencies registered above. Intellectually, this has turned into an inadmissible weakness indeed. 


\section{QUANTITY VERSUS QUALITY?}

In the previous section, we considered territorial and institutional decentralization to be a plus for a small country with disproportionate focus on the capital city. This feature applies to all new members with the partial exception of Poland, where prestigious research universities in Krakow, Poznan and many other cities compete with the Warsaw establishments.

Meanwhile, everything seems to come at a price. What is a plus in one dimension might and often does count as a minus in a different dimension. Increasing student numbers is a plus from the perspective of democratization and fostering social mobility. It also is creating competition for jobs, and helps improve the employability of a larger pool of people, thus is commendable. On the other hand, ifunlike during the interwar period in Hungary - governmental spending remains limited, the same practice may and often does create a serious quality problem. All the more so, if these spending items are not being supplemented by those private expenditures which are, especially in the USA, being fostered by lavish tax brakes and student loans. Corporate funding of research in general and of university quality education in particular has remained limited, which is due to a combination of cultural factors - such as the preeminence of foreign owners who are emotionally not really attached to the local culture -, weak middle classes, overall myopia and consumerism as formative societal values, and certainly the inadequate appreciation of such spending by the tax system.

Under these circumstances territorial and institutional decentralization translated also into what we may qualify as fragmentation of research and teaching. As each school is in a need of a European Studies and International Relations department, they build up one, even if faculty and other conditions of high quality teaching, as libraries and other facilities, are rather limited. Joining forces were, in terms of administration and academic output, desirable, although it runs counter to the elementary logic of those power games that are inherent in territorial structures of political organization. Recurring governmental attempts to cut back the number the institutions of higher education - one currently coming to its end at the time of writing - have invariably foundered upon the joint resistance of local powers, politics, business, intellectuals and the press.

The second weakness is perhaps, at least in part, an outcome of the first. This is methodological weakness, which follows from multidisciplinarity and pragmatism just as much as from the territorial and institutional overstretch characterizing the area. While in theory one could easily visualize one school with an economic focus, thus, applying basically economic methodology, while the other focusing on IR theories and related - often postmodernist, poststructuralist method- 
ology - such delineation rarely takes place. For this reason the output is not only uneven, but teaching at the graduate and postgraduate level cannot be built on sound preliminaries. Limited, if any, improvement in the command of foreign languages, especially at the active/conference level is a further constraint. It is true that Erasmus and other mobility and exchange programs continue to improve faculty and student output, but these ad hoc measures, which are limited in time and general in purpose, hardly make up for the lack of better structured multilayer curricula, especially for the advanced levels. Good performance of top students from top schools are appreciated, but they cannot overshadow the weakness of the broad middle of the road.

The third major weakness was already implied by our preceding discussion of the nature of the academic output, with the pre-eminence of descriptive and policy-oriented pieces and the virtual lack of theory-based and broader academic pieces and the related discussion thereof. Following the major journals of European Studies, we find decreasing presence of authors from the new EU members, including Hungary, except for invited papers or multilateral conference proceedings/special issues. While academics from small nations rarely contribute to the mainstream of any of the established disciplines, be that economics or political philosophy, it is surprising to register their rather limited presence in a field that enjoys high prestige and publicity inside the countries and on the EU level alike. ${ }^{2}$ If the output is more imitative than innovative, using this brutal shorthand, then the explanation is more straightforward.

As fourth, we may establish that most of the output of new members, and Hungary in particular, is focused on the assessment and investigation of present policies and institutions. This implies a positively backward-looking approach, insofar as the reform of major expenditure areas is already in the making, in the context of elaboration of the Financial Guidelines for the 2014-2020 period. Also the reform of existing institutions has been on the agenda for ages, and one of the few things we may forecast with certainty that a Community of 27 and later 29 or more members is unlikely to be able to function without major reforms of institutions and decision-making (more on that in Csaba 2009).

This state of affairs is burdened with at least two further ramifications. Firstly, researchers and, thus, policy-makers of the region are unlikely to be well prepared for the changes in the future, whatever final shape these may eventually take. Secondly, it also implies that academics from the region have less and less to offer, as their attention is not focused on the progressive areas, which are to shape the future, such as the Lisbon Strategy, energy security, climate change, immigration, neighborhood policies and the like. It is a problem on its own right and even more of a problem for future policy-oriented research and useful knowledge in general, 
to allow for a large degree of built-in obsolescence in the stock of knowledge available, produced and transmitted to future generations.

Finally, a further feature, often listed among the strengths, should be listed among the weaknesses. Contributions from the new member-states in general and from Hungary in particular tend to focus on only one aspect of the Common Foreign and Security policy, namely the Eastern dimension of the European Neighborhood Policy. This is often supported by arguments highlighting the allegedly unique historical grounding of the insights, especially of Poland and Hungary, in managing affairs in the Balkans and also in the Commonwealth of Independent States. While this approach is not strongly present in the academia, it has traditionally been shaping the atmosphere of deliberations and policy discourses in and about the ENP.

Let us mention two features why this approach is a dangerous fallacy, if taken seriously (as it seems to be the case). Firstly, historic involvement of both Poland and Hungary has been one of dominance in the respective regions. For this reason the century which followed has seen a flaring up of national consciousness, reflected first in the undercurrent of nationalism (always denied by the rulers) in the federal states of Yugoslavia, Czechoslovakia and the Soviet Union. Later those tectonic movements have resulted in the birth of a series of new states (which, ironically, remained in their most part as multi-ethnic as their predecessors, from Ukraine to Macedonia). For this reason, any patronizing approach, tones of fathering, or even the pronounced presence of historically dominant nations in any other form than part and parcel of the European unit, can only be counterproductive.

Secondly and intimately related to the former, historic experiences are, to their most part, of limited, if any, value to understanding current problems. The latter results from the collapse of the totalitarian state, the disintegration of large and smaller empires, the unfinished nature of Europeanization, the fragmentary and often inefficient management of the process of transnationalization and globalization by the local elite, and the limited ability of domestic societies to keep pace with the breath-taking pace of historic and economic changes of the post-1989 decades. In short, it is the new rather than the old challenges that need to be tackled. And nobody familiar with the broad theory of path dependence would doubt the relevance of the past for the present and the future. It would certainly be $a$ misreading of the tasks if geographical proximity alone would become a formative factor. In countries, where - again with the partial exception of Poland - area studies departments and Eastward and Southward looking research centers tended to be disbanded, merged or severely underfunded, urban legends and family remembrances can hardly substitute the missing analytical capabilities in the region. 


\section{ADDITIONALITY AND COMPLEMENTARITY}

What has been presented above already foreshadows our - critical - assessment of the opportunities constrained by the overall organization of this research area in the new member-states. With a few exceptions, including my mother department of International Relations and European Studies at the private American CEU, not many departments are organized around the issue of Europeanization. This is perhaps a result of improvised and market-following rather than strategic adjustments to the tidal changes of demand described in the preceding sections.

The usual way of organizing the supply response has been the extension of pre-existent departments and faculties, with simple additive processes, rather than elaborating strategic projects and managing those via reorganizations, as suggested by the literature on business administration. What makes this issue truly interesting and even intriguing is that this outcome has not only been observed in the old, established institutions, where the sociology of large organizations (Miller 1992) would suggest the resistance of pre-existent power groups against any new winds of major change.

Also in the new schools, often created from scratch, or on the basis of institutions with a truly different profile, such as provincial humanities and engineering colleges in the majority of cases, the replication of old patterns with the additive approach could be traced. Therefore, it was typical to pick one lead scholar, from whatever area, on the base of personal availability, and build smallish research-subgroups, or similarly structured teaching sub-units within the 'respectable' departments of economics/international economics, law, political science and geography/regional studies.

This arrangement has its pluses, insofar as the multidisciplinarity of approaches is a given for European studies. On the other hand, this receives a very uneven and coincidental coloring, depending on traditions and people rather than any abstract - let alone formal - criterion of competitiveness and inter-school compatibility. As long as research has not become a formative component of university careers - as opposed to the number of classes taught and other controlling variables - cooperation across the departments could not use its potential to remedy the above listed shortcomings in the most trivial and efficient fashion, i.e. by setting up joint projects and regular workshops within the country and also internationally. While such occasions do occur, these happen mostly as an unintended outcome of EU wide projects, or of the initiatives of Western colleagues, i.e. on an ad-hoc basis.

This is perhaps a second organizational weakness we should expose, namely the ad-hoc nature of networking. Twenty years after the systemic change we still have to see the emergence of such networks as the British Association for Soviet 
and East European Studies, or the European Studies Association, within most of the new members. The above mentioned networks organize regular annual workshops, international gatherings, publish journals and book series. In short, they act as catalysts for new ideas, people, publications, research and intellectual interaction across people active in a given field. The underfunding, as criticized above, and the ensuing overdose of teaching - mostly of undergraduates and auxiliary learners, basically for financial compensation, rather than achieving academic excellence, together bear the lion's share of responsibility for this sad state of affairs.

The fourth organizational weakness follows from the previous three. As curricula are not standardized, not even at the introductory level, it is difficult to create compatibility across schools. Even less is it possible to build on knowledge acquired by the students at the undergraduate level. This of course diminishes academic quality - and also the appeal - of graduate level courses, often containing overlaps in order to secure certain minimum standards. Likewise, it is close to impossible to enrich EU related knowledge in a structured fashion, say by taking an $\mathrm{MA} /$ European Law orientation to complement an EU/economics or EU/business one. Course patterns are often contingent upon interest - and motivation - of faculty, i.e. supply-led, rather than following market demand, or any standardized academic output criteria, which are quite usual to be set, from medicine, via engineering to legal studies.

Last but not at all least it seems to be a positive drawback to observe the continued pre-eminence of legal and institutional focus, relying on descriptive methods, at the expense of broader academic approaches. Moreover, there is a tendency to neglect output from, and implications of, developments in the competing/complementary disciplines, more specifically economics, international relations, democratic theory, business administration and regional studies. The weak economic anchoring is reflected in the poor understanding of the rather palpable advantages of existing arrangements, primarily the single currency and the single market as the driving forces of a multitude of benefits and consumer surplus, both at microand macro-levels. By the same token often unprofessional suggestions are being floated, and by far not only in the tabloids and the entertaining electronic media. The relevance of civil society and its activism in fostering such progressive areas of European policies, as environmental protection, social rights, gender equity, rule of law, non-discrimination across people and institutions along their national lines, equal treatment of guest workers, the need to combat terrorism via coordinated measures or the interrelationship between the single market and energy security, are poorly understood if at all. It is true that all the progressive policy areas have one in common, namely the evolutive, bottom-up nature, which is obviously at odds with the top-down nature of legal thinking as well as that of intergovernmentalism, still dominating the political science debates on the EU (while 
declining in all other areas within this discipline). It is sad and telling that studies of NGOs and other grass roots movements, though being instrumental in triggering as well as implementing and monitoring progressive policy fields of the EU, from environmental protection to equal opportunity programs at the national level, tend to be excluded from the curricula, or studied separately in sociology and specialized political science courses in most of the schools I am familiar with.

\section{PERSPECTIVES}

Even from the perfunctory overview of the state of affairs, it follows that any forward-looking strategy in teaching, and even more in research, should focus on issues that will grow in significance. Let the past to be uncovered by historians. For this reason we would call for enhancing the theoretical and methodological foundations of the field, and going away from the old patterns, which would include reliance on the more abstract approaches in economics, in political science, in international relations as well as in sociology (see for example Wallace - Wallace Pollack, eds 2005). This is not necessary and not even possible to be done in every single school. On the contrary, in our ideal scenario each school should develop a profile, over and above being able to deliver the standard(ized) knowledge for undergrads and also for the MA level. Cooperation across the schools, but also formalization of cooperation across the border, would be the best test if and how progress has been achieved. This type of research is likely to receive funding both from the business community and the state administration.

Our second suggestion would call for a more economic anchoring of the area. This is not to be related to the 'economic imperialism' of the Gary Becker (1993) type, aiming to interpret any social and individual phenomenon through the lense of microeconomics. Rather, our insight follows from the observation that the EU is based, to a large degree, on economic arrangements. These include most importantly the single market and the single currency, the customs union, the common foreign trade policy, the cohesion policies and a number of further areas, from farming to climate change, where common principles guide national expenditures in a formalized fashion. If this is the case, fundamental insights, originating to a large degree from economic theory, should be fed back to the students of the re-

lated areas listed above (without being too technical or positively exhaustive, of course).

A third set of tasks is the need to regularize networking, both in the academic/civil sphere and at the level of universities and colleges. What we are driving at is not yet another Framework Program, with its unduly focus on economies of scale. For it is well known that except for bureaucratic convenience, there is no 
sound argument in favor of 'economies of scale' in the social science research (and research in general). This insight is in line with the growing role of small business, including spinoffs, in triggering innovations and patenting, against the huge government sponsored organizations who are, at best, good at producing research reports, documenting the spending of the sponsor's money, rather than generating new insights and practical uses.

From this analysis it follows that future research cooperation should not always and not necessarily include ministries and fora with 27 and more participants as a rule. Rather, plurilateral and flexible forms of organization, relying to a great degree on the open method of coordination, should be invoked (Rodrigues 2003). This allows for changing constellations and much imitation, informalism, on the spot learning and other forms of obtaining tacit knowledge, rather than trying to maximize 'drawable' funds, or spend them once they have been allotted, whether or not these breed value added.

Fourth, enhancing faculty mobility seems to have become a major concern in terms of practicality. If and when senior faculty migrate, rather than just shuttle, from the new member states, it is hardly beneficial for upgrading economic education and research in the region (Bourgignon et al., eds 2007). While we think that preserving the closeness to business and policy practice is certainly a plus, teaching Europeanization by those who have not been seriously involved, especially not via a common filtering pattern and joint academic peer reviews, is certainly yet another component of what we termed built-in obsolescence above. Delivering courses at sister universities, developing courses that are, by definition, compatible for Erasmus students with those offered by their home institutions, are the way forward, rather than convening yet another meeting of the top bureaucrats. The latter has fuelled and sustained the ill-fated Bologna process of producing ever lower quality student output EU wide.

It goes without saying that faculty mobility should not focus on academic bureaucracies signing contracts and framework agreements, but should cover junior faculty. The latter could capitalize more and transplant more efficiently both professed, formalized and tacit knowledge which is instrumental in EU-wide networking, more often than not at the regional and local, corporate or departmental levels.

In assessing prospective tasks, our starting point cannot be else but the journalistic platitude that knowledge is global, but all applications are local, if these aspire to be practical and relevant. Any novelty counts as an innovation only if it comes first in the world, or performs better globally rather than on the local/national scale. On the other hand, any of those insights matter only if it can be put in the local context, interpreted for the local society and accepted by the latter. Therefore, our target function cannot be any equalization at the level of institu- 
tions. Rather, we require an attempt to build new centers of excellence and networks across those, which produce palpable value added for the quality of teaching and research. Money should increasingly be directed towards those ends, rather than sustaining expenditure patterns not justified by other considerations than tradition and vested interest bargaining, thus, falling short of producing this palpable value added.

In the future more use could be made of the regional diversity of the faculty in old and new member-states alike. Given the growing relevance of the regional dimension in economic development, emphasized inter alia - though not exclusively - by the highly fashionable new economic geography approach and the fact that it figures traditionally highly among the spending priorities of the EU, this is certainly an underused potential. Firstly, studies already made in understanding the causes and consequences of regional differentiation in the EU, the limited progress made in terms of convergence, is an issue on its own right. Secondly, by twinning non-trivial and non-traditional partners much of the currently covert potential of knowledge transfer could be exposed. This might be particularly helpful for countries where this is and will remain a major issue, such as in the cases of Romania, Bulgaria, Hungary and Poland, but also Greece, Spain and the Nordic members. Once again, small-scale trilateral or plurilateral rather than grandiose, Brussel-based 'all-inclusive' projects might bring the benefits mentioned. If those represent real local interest, co-funding might be forthcoming both from Brussels and the local business community.

It goes without saying and follows from the basic principle of unity in diversity that various member-states of the EU have rather different stakes in diverse aspects of the ESDP, the CFSP and the ENP, while they do have a common stake in Justice and Home Affairs. While Mediterranean members might contribute not only to their traditional fields of the Barcelona process, but also to disentangling the complexities of Turkish membership, Eastern members could also be much more active than before. Firstly, by relying on their better relationships with the US, they could smoothen dialogue with Washington. They could be more practical in contributing to a better and more forward-looking strategy on the Western Balkans. In the latter area, state building and integration goes hand in hand (or both of them stagnate, as one could observe in the past years). In doing so, perhaps they cannot take over the initiative from the big nations, but they could initiate practical steps towards customs union, free trade, fighting criminality and consequences of the war, rooting out human trafficing and strengthening the new democracies in the region. They could act as advocates of the small and weak West Balkan nations and countervail the tendency to crowd out this unpleasant, while unresolved set of issues from the agenda of policy-making. Thirdly, new members could sustain the ties with smaller new independent states in order to strengthen 
their independence and European orientation, again not replacing the bigger and financially more prosperous players of the EU.

A further urgent practical job would be to develop coordinated curricula in European studies. While one would like to see this happen also in areas like history, or legal studies, in our field of European Studies such initiatives are perhaps easier to manage, being less emotionally loaded and of higher practical and business relevance. The evolution of coordinated $\mathrm{BA}, \mathrm{MA}$ and in part $\mathrm{PhD}$ level curricula could help create compatibility, competition and higher standards for the large number of new schools and especially enhance the labor market value of school leavers from this particular area.

One of the most important areas of immediate improvement potential is to enhance the possibilities for field work. This could be easily promoted by EU level agreements on funding and quasi-automatic admission procedures to public organs and corporations alike (on par with the nationals). In doing so, a lot could be done to overcome the current distaste for European integration, especially in the core EU nations. Likewise sending Western faculty to new members to teach and also learn, might perhaps be the best way to overcome prejudices. Last but not least, field research helps generate feedback and useful knowledge, both for policy-making and the business community.

Yet another prospective areas of joint action would be to revive and sustain the practice of joint publications, reflecting joint research. This could be both in the form of relying on international publishing houses, such as Akadémiai Kiadó in Hungary, or Karolinum Press in the Czech Republic. English becoming the sole means of communication in the academia allows for, but also incites, the inclusion of new outlets for new ideas. Publishing international journals with international editorial boards is though an ongoing practice, it is still to institutionalize the exchange of ideas to the level it would be desirable. While such developments flourished in the immediate post-transition period, the past decade has experienced a lower ebb, contributing to the further Americanization of entire disciplines. It is telling that most leading European economics journals are already being outsourced to the Americas, while the discourse on the European model and Lisbon Strategy knows no end.

Finally, one should mention a number of potential public policy initiatives. These become all the more relevant the more we manage to overcome the usual national inhibitions and the misleading focus on net contributions to the budget. As the latter position is about to be equalized by the end of the current financial guideline, it might be more meaningful to rally according to academic convictions. As long as enhancing efficiency, functionality, transparency and observance of simple but powerful public finance principles could be in the focus of deliberations, the Financial Guidelines for the 2014-2020 period could potentially 
see the advent of major efficiency and competitiveness improving reforms. In order to attain this, the currently prevailing blocking coalitions should be replaced by coalitions of principled and committed Europeans, who do have clear and publicly defensible European objectives other than maximizing 'drawables'.

In order to attain these broad objectives, the re-launch of the 2005 edition of the Lisbon Strategy for at least a decade more, adopting joint policies on energy security, further enlargements, climate change and implementing the controversial Immigration Pact of June 2008 (Carrera - Guild 2008) could form the backbone of such a strategy. More focus on research cooperation, based on joint principles rather than financial and bargaining power, as was the case with the Framework Programs, could contribute to a new form of European cohesion. As we have seen before, this does not imply, in the majority of cases, more spending, rather that expenditures should be more targeted on externalities and creating measurable value added.

\section{REFERENCES}

Becker, G. E (1993): The economic way of looking at behavior. Journal of Political Economy 101(3): 385-401.

Bourgignon, F. et al., eds. (2007): Upgrading Economics Education and Research: The Experience of Emerging Economies. Washington, D.C.: The World Bank.

Carrera, S. - Guild, E. (2008): The French presidency's European Pact on Immigration and Asylum. Brussels: CEPS Policy Brief, no. 170/18, accessed at: www.ceps.be on 24 June,2009.

Csaba, L. (2007): The end of accession-driven transition. In: Csaba, L.: The New Political Economy of Emerging Europe $-2^{\text {nd }}$ revised and extended edition. Budapest: Akadémiai Kiadó, chapter 7.

Csaba, L. (2009): Crisis in Economics? Studies in European Political Economy. Budapest: Akadémiai Kiadó.

Daianu, D. (2009): Which Way Goes Capitalism? New York-Budapest: CEU Press.

Farkas, B., ed. (2007): A lisszaboni folyamat és Magyarország [Impacts of the Lisbon Strategy on Hungary]. Szeged: JATE Press.

Inotai, A. (2007): The EU and Southeast Europe: Troubled Waters Ahead? Frankfurt-Bern-New York: Verlag Peter Lang.

Kádár, B. (2008): Our deficits. Public Finance Quarterly 53(2): 173-185.

Miller, G. (1992): Managerial Dilemmas: The Political Economy of Hierarchy. Cambridge-New York: Cambridge University Press.

Palánkai, T. (2004): Economics of Enlarging of the European Union. Budapest: Akadémiai Kiadó.

Polónyi I. - Szilágyi, E. (2008): Felsőoktatási privatizáció, felsőoktatási vállalat vagy vállalkozó felsőoktatás? [Privatizing higher education, corporate forms of higher education or enterprising higher education?] Közgazdasági Szemle, 55(3): 262-277.

Rodrigues, M. J. (2003): European Policies for a Knowledge Economy. Cheltenham-Northampton: Edward Elgar.

Török, Á. (2008): Science or competitiveness? Science and competitiveness! Public Finance Quarterly 52(4): 557-580. 
Trauner, F. (2009): From membership conditionality to policy conditionality: EU external governance in Southeast Europe. Journal of European Public Policy 16(5): 774-790.

Wallace, W. - Wallace, H. - Pollack, M., eds. (2005): Policy-Making in the European Union - $5^{\text {th }}$ revised edition. Oxford: Oxford University Press.

Winiecki, J., ed (2009): Competitiveness of New Europe. London: Routledge.

\section{NOTES}

1 This is a revised and updated version of a paper delivered to the international conference of Complutense University, Madrid, 24-27 March 2009. A Spanish version of selected papers is forthcoming at La Catarta Publishing House, under the editorship of Fernando Luengo. It is instructive that a recent broad analysis of European models (Daianu: 2009) has received a broad IR-implying title. 